\title{
Effect of Training and Work Environment on Employee Performance at PT Marindo Makmur Usahajaya Sidoarjo
}

\author{
Annisa Dwi Permatasari, Bayu Airlangga Putra, SE., MM, Elok Damayanti, SE, MM \\ Faculty of Economics and Business, Narotama University Management Study Program \\ Jl. Arief Rahman Hakim 51 Surabaya, East Java, Indonesia \\ Annisadps24@gmail.com, Bayu.airlangga71@gmail.com, elok.damayanti@narotama.ac
}

\begin{abstract}
This study discusses how the influence of training and work environment on employee performance at PT Marindo Makmur Usahajaya Sidoarjo. This study aims to determine the effect of training, work environment on employee performance. The sampling technique in this study used the Non Probability Sampling method. Respondents in this study were 83 employees. Methods of data analysis using multiple linear regression test, with SPSS v.18 software as an analysis tool.The results of this study indicate that training variables and work environment variables partially and simultaneously have an effect on employee performance.
\end{abstract}

Keywords :

Employee Performance, Training, Work Environment

\section{Introduction}

One of the company's efforts to maintain employee performance is to maintain several important factors for optimal work results. In big cities, more and more people spend their time in companies because of job demands that are sometimes difficult to avoid. If you have this, the company seems to be a frightening specter for its employees. In fact, human resources (HR) have a very influential role in the performance and positive growth of a company.

Every organization or company that succeeds in achieving its goals will try to make the best use of its resources. One of these resources is human resources. Human resources are the most important organizational or company asset in determining the success or failure of a company, because they are the ones who drive and act as actors in work activities and actors in economic activities.

Employees are a very important and attractive part because their benefits prove to be very important. Therefore, efforts to improve employee performance are the most serious management challenges because the success in achieving the goals and survival of the company is very dependent on the quality of the performance of its human resources.

PT Marindo Makmur Usahajaya (MMU) is a company engaged in the export of marine products. Therefore, the company understands the importance of creating a conducive and healthy work environment. The work environment can have positive and negative impacts for employees to achieve their work results.

The work environment in a company is very important for management to pay attention to. Even though the work environment does not carry out the production process in a company, the work environment has a direct influence on the employees who carry out the production process. A comfortable work environment for employees can improve performance. Conversely, an inadequate work environment will reduce performance. Performance is said to be good or appropriate if humans can perform activities optimally, healthy, safe and comfortable.

On an ongoing basis, the company also continues to strive to improve HR capabilities through effective development programs. In the world of work our ears are familiar with the term job training or training. Where is the process of increasing the skills or abilities needed by new employees and old employees to do work. New employees or those who are already working need to attend training because job demands can change due to changes in the work environment, strategies, and so on.

The company provides regular training programs with the same material (refresh) which aims to make employees more familiar with SOPs because so far there are still some employees who are negligent in their work (old or new employees).

In addition, the company organizes training programs due to cooperation with certification, sedex, etc. Training can affect employee performance, even more than the appraisals and feedback provided to employees. 
Training is conducted twice a month inside the company and once a year outside the company. There are ten to fifteen participants who take part in the training per meeting if the system is Off the Job Training. However, if it is On the Job Training (OJT) the participants who take part are all employees.

From the description of the background above, this research is interested in studying training, work environment on employee performance, so the researcher examines it with the title "The Effect of Training and Work Environment on Employee Performance".

\section{Literature Review}

\subsection{Training}

Job Training is an effort to improve the quality of human resources in the world of work. Employees, both new and already employed, need to take part in training because there are jobs that can change due to changes in the work environment, strategies, and so on. Job training is related to the skills and abilities required for the current job. Job training is oriented to the present and helps employees to master specific skills and abilities (competencies) to succeed in their jobs. According to Dessler (2011) job training is the process of teaching new or existing employees the basic skills they need to carry out their jobs.

\subsection{Work environment}

According to Sedarmayanti (2013) suggests that a place has a group in which there are several supporting facilities to achieve company goals in accordance with the company's vision and mission. Meanwhile, Suwatno and Priansa (2011) defines the work environment as factors outside humans, both physical and non-physical in an organization.

From the opinions of experts, it can be concluded that the work environment is everything that is around the employee at work, both physical and non-physical which can affect employees at work. If the work environment is conducive, employees can be safe, comfortable and if the work environment is not supportive, employees cannot be safe and comfortable.

\subsection{Employee performance}

According to Mangkunegara (2011) employee performance is the result of work in quality and quantity achieved by an employee in carrying out his duties in accordance with the responsibilities assigned to him. Based on the above explanation, performance is a result achieved by a person in carrying out tasks based on skills, experience and seriousness and time according to predetermined standards and criteria.

Performance according to Hasibuan (2012) is a result achieved by a person in carrying out the tasks assigned to him based on skills, experience, and seriousness and time.

From the above understanding, it can be formulated that basically. Performance is the result of work that has a strong relationship with the organization's strategic objectives, customer satisfaction, and contributes to the economy and performance is an effort or effort in managing human resources that are performance-oriented employees who carry out an open and sustainable communication process by creating a shared vision and strategic and integrated approach as a driving force to achieve organizational goals. Performance is the work achieved by a person in carrying out tasks in accordance with the responsibilities given during a certain period of time.

\subsection{Framework of Thinking}

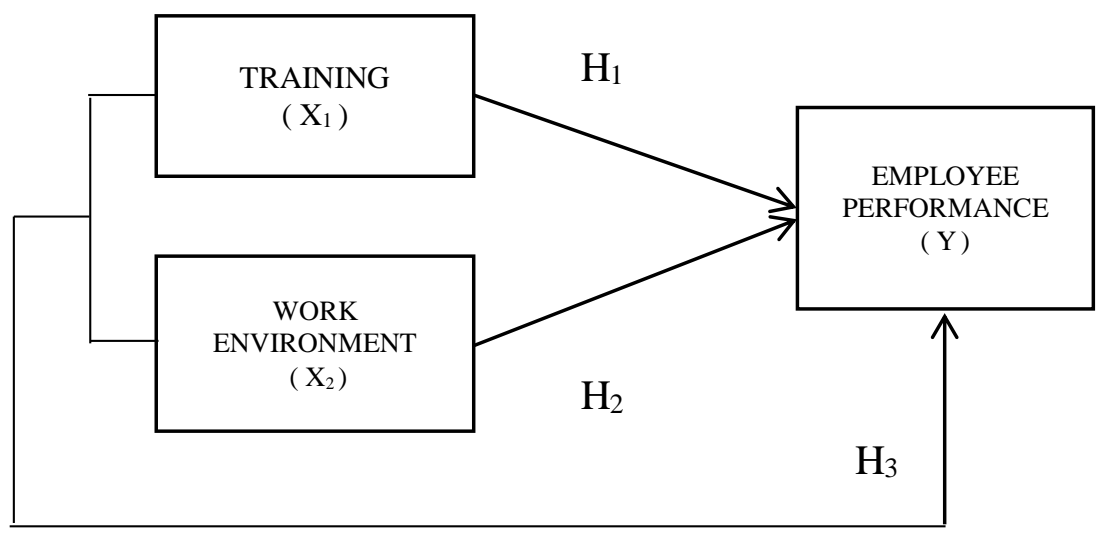

Figure 1. Framework of Thinking 


\subsection{Hypothesis}

Based on the research framework above, the following research hypothesis can be formulated:

H1: Training has a partially significant effect on employee performance

$\mathrm{H} 2$ : The work environment has a partially significant effect on employee performance.

H3: Training and work environment simultaneously have a significant effect on employee performance.

\section{Research Methods}

\subsection{Population and Sample}

This type of research used in this research is quantitative research methods. According to Sugiyono (2013) quantitative research methods can be interpreted as a research method based on the philosophy of positivism, used to research on certain populations or samples, sampling techniques are generally carried out randomly, data collection uses research instruments, data analysis is quantitative / statistical with purpose to test the hypothesis that has been set. The object of research is something that becomes a reason for conducting research, the object of research is the goal of finding answers and solutions to problems that occur. The research object in this research is the employees of PT Marindo Makmur Usahajaya Sidoarjo. The population in this study were 83 employees of PT Marindo Makmur Usahajaya. The sampling method used in this study is to use the Non Probability Sampling method, namely convenience sampling where members of the population can be easily selected as the sample.

\subsection{Multiple Linear Regression Analysis}

Regression analysis is used to determine the dependence of the dependent variable with one or more independent variables with the aim of estimating and / or predicting the population mean or average value. The dependent variable is based on the known value of the independent variable.

With the formula:

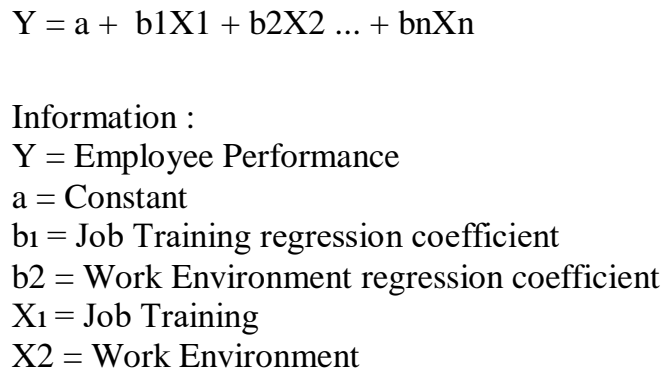

To find the values of a and $b_{1}, b_{2}$ the following formula is used: b1 $=((\Sigma x 1 y)(\Sigma x 2 y)-(\Sigma x 2 y)(\Sigma x 1 \times 2)) /\left(\left(\Sigma x 1^{\wedge} 2\right)(\Sigma \times 2 \wedge 2)-(\Sigma x 1 \times 2)^{2}\right)$

$\mathrm{b} 2=((\Sigma \mathrm{x} 2 \mathrm{y})(\Sigma \mathrm{x} 1 \wedge 2)-(\Sigma \mathrm{x} 1 \mathrm{y})(\Sigma \mathrm{x} 1 \mathrm{x} 2)) /\left(\left(\Sigma \mathrm{x} 1^{\wedge} 2\right)\left(\Sigma \mathrm{x} 2^{\wedge} 2\right)-(\Sigma \mathrm{x} 1 \mathrm{x} 2)^{\wedge} 2\right)$

$\mathrm{a}=(\Sigma \mathrm{Y}-\mathrm{b} 1 \Sigma \mathrm{x} 1-\mathrm{b} 2 \Sigma \mathrm{x} 2) / \mathrm{n}$

\section{Results and Discussion}

\subsection{Test Validity and Reliability}

Data processing used in this study used statistical pasw version 18, by determining the conclusion for the validity test, namely the 2 -sided test of 0.05 significance where if $r$ count $>r$ table then the instrument statement items have a significant correlation to the total score or are declared valid. If $r$ count $<r$ table, the statement instrument which has a significant correlation to the total score can be declared invalid. 
Table 1. Test Validity

\begin{tabular}{|c|c|c|c|c|}
\hline Variabel & Indikator & $\begin{array}{l}\text { Corrected Item-Total } \\
\text { Correlation }\end{array}$ & R-Table & Keterangan \\
\hline \multirow{8}{*}{ Training (X1) } & $\mathrm{X} 1.1$ & 0,602 & 0,22 & Valid \\
\hline & $\mathrm{X} 1.2$ & 0,561 & 0,22 & Valid \\
\hline & $\mathrm{X} 1.3$ & 0,538 & 0,22 & Valid \\
\hline & $\mathrm{X} 1.4$ & 0,719 & 0,22 & Valid \\
\hline & X1.5 & 0,698 & 0,22 & Valid \\
\hline & X1.6 & 0,737 & 0,22 & Valid \\
\hline & $\mathrm{X} 1.7$ & 0,721 & 0,22 & Valid \\
\hline & $\mathrm{X} 1.8$ & 0,693 & 0,22 & Valid \\
\hline \multirow{8}{*}{$\begin{array}{l}\text { Work environment } \\
\text { (X2) }\end{array}$} & $\mathrm{X} 2.1$ & 0,444 & 0,22 & Valid \\
\hline & X2.2 & 0,446 & 0,22 & Valid \\
\hline & $\mathrm{X} 2.3$ & 0,763 & 0,22 & Valid \\
\hline & $\mathrm{X} 2.4$ & 0,705 & 0,22 & Valid \\
\hline & $\mathrm{X} 2.5$ & 0,725 & 0,22 & Valid \\
\hline & X2.6 & 0,71 & 0,22 & Valid \\
\hline & $\mathrm{X} 2.7$ & 0,762 & 0,22 & Valid \\
\hline & $\mathrm{X} 2.8$ & 0,753 & 0,22 & Valid \\
\hline \multirow{11}{*}{$\begin{array}{c}\text { Employee } \\
\text { performance (Y) }\end{array}$} & X2.9 & 0,706 & 0,22 & Valid \\
\hline & Y.1 & 0,745 & 0,22 & Valid \\
\hline & Y.2 & 0,741 & 0,22 & Valid \\
\hline & Y.3 & 0,729 & 0,22 & Valid \\
\hline & Y.4 & 0,71 & 0,22 & Valid \\
\hline & Y.5 & 0,774 & 0,22 & Valid \\
\hline & Y.6 & 0,674 & 0,22 & Valid \\
\hline & Y.7 & 0,642 & 0,22 & Valid \\
\hline & Y.8 & 0,724 & 0,22 & Valid \\
\hline & Y.9 & 0,626 & 0,22 & Valid \\
\hline & Y.10 & 0,677 & 0,22 & Valid \\
\hline
\end{tabular}

Based on the results of the validity test according to the table above for all dimensions it states that of the 27 statement items used can be said to be valid.

\subsection{Reliability test}

Table 2. Reliability Test

\begin{tabular}{ccc}
\hline Variabel / indikator & Alpha & Keterangan \\
\hline Pelatihan Kerja & 0,812 & Reliabel \\
Lingkungan Kerja & 0,852 & Reliabel \\
Kinerja Karyawan & 0,886 & Reliabel \\
\hline
\end{tabular}

Based on the reliability test table above, this research data has a Cronbach's alpha value of 0.812 in training (x1), 0.6522 in the work environment (x2), 0.886 on employee performance, and more than 0.5 with 27 statement items. for Then the data is declared reliable. 


\subsection{Classic assumption test}

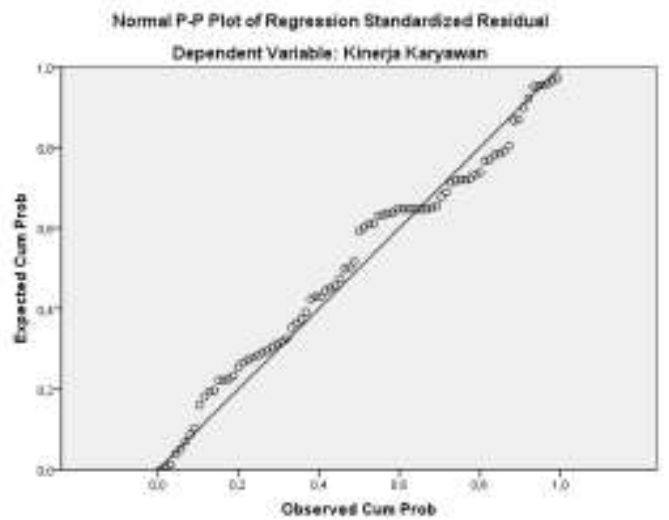

Figure 2. Classic assumption test

Based on the graph above shows that all existing data are normally distributed, because all data spread in a diagonal straight line then the data meets the normal assumption or follows the normality line.

\subsection{Kolmogorov Smirnov Normality Test}

Table 3. One-Sample Kolmogorov-Smirnov Test

\begin{tabular}{ccc}
\hline & & $\begin{array}{c}\text { Unstandardized } \\
\text { Residual }\end{array}$ \\
\hline \multirow{2}{*}{ Normal Parameters ${ }^{\mathrm{a}, \mathrm{b}}$} & $\mathrm{N}$ & 83 \\
& Mean &, 0000000 \\
Most Extreme Differences & Std. Deviation & 3,81696607 \\
& Absolute &, 099 \\
& Positive &, 073 \\
& Negative &,- 099 \\
Kolmogorov-Smirnov Z &, 905 \\
Asymp. Sig. (2-tailed) &, 386 \\
\hline
\end{tabular}

a. Test distribution is Normal.

b. Calculated from data.

Based on the results of the normality test, it is known that the significance value is $0.386>0.05$. So it can be concluded that the residual value is normally distributed.

\subsection{Multicollinearity Test}

Coefficients $^{\mathrm{a}}$

Table 4. Multicollinearity Test

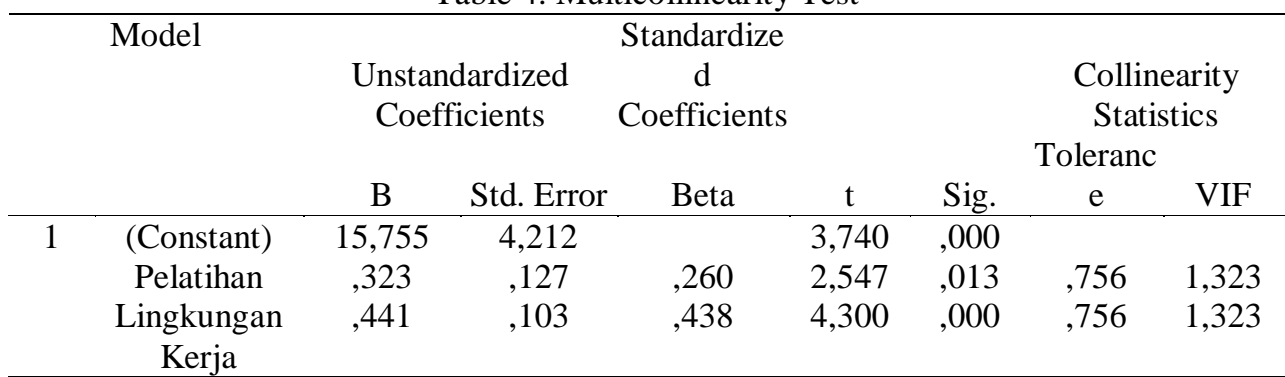

a. Dependent Variable: Kinerja Karyawan

Based on the table above, the calculation of the tolerance value shows that all independent variables have a tolerance value greater than 0.10 . The result of the calculation of the variance inflation factor (VIF) value shows that all independent variables have a VIF value of less than 10. The VIF value of the X1 and X2 variables is 1,323.10. So it can be concluded that there is no multicollinearity in the regression model. 


\subsection{Heterokedas Ticity Test}

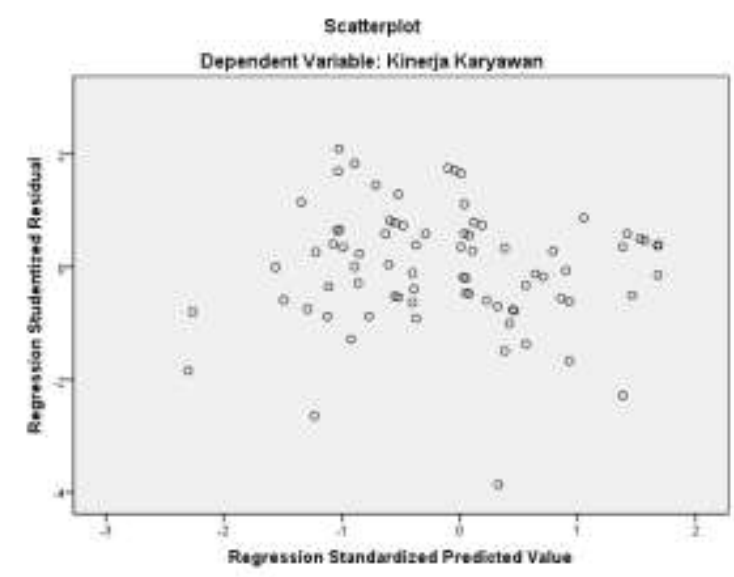

Figure 3. Heterokedas Ticity Test

Based on the graphic image above, it can be seen that the data distribution is irregular and does not form certain patterns, and is spread above and below the number 0 on the $\mathrm{Y}$ axis, so it can be concluded that in this regression model there is no heteroscedasticity problem.

\subsection{Park Test}

Coefficients $^{\mathrm{a}}$

Table 5. Park Test

\begin{tabular}{ccccccc}
\hline & Model & \multicolumn{5}{c}{ Standardized } \\
& & \multicolumn{6}{c}{ Unstandardized Coefficients } \\
& & B & Std. Error & Beta & $\mathrm{t}$ & Sig. \\
\hline 1 & (Constant) & 3,033 & 8,628 & &, 352 &, 726 \\
& Lnx1 &, 268 & 2,459 &, 014 &, 109 &, 913 \\
& Lnx2 &,- 732 & 2,173 &,- 042 &,- 337 &, 737 \\
\hline
\end{tabular}

a. Dependent Variable: Lnei2

Based on the table above by looking at the P value, namely in the sig column. If the sig value $>0.05$, there are no symptoms of heteroscedasticity.

\subsection{Multiple Linear Regression Analysis}

Coefficients $^{\mathrm{a}}$

Table 6. Multiple Linear Regression Analysis

\begin{tabular}{|c|c|c|c|c|c|c|}
\hline & \multirow[t]{2}{*}{ Model } & \multicolumn{2}{|c|}{$\begin{array}{l}\text { Unstandardized } \\
\text { Coefficients }\end{array}$} & \multirow{2}{*}{$\begin{array}{c}\text { Standardized } \\
\text { Coefficients } \\
\text { Beta }\end{array}$} & \multirow[b]{2}{*}{$\mathrm{t}$} & \multirow[b]{2}{*}{ Sig. } \\
\hline & & B & Std. Error & & & \\
\hline \multirow[t]{3}{*}{1} & (Constant) & 15,755 & 4,212 & & 3,740 & 000 \\
\hline & Pelatihan (X1) & ,323 & , 127 & ,260 & 2,547 & ,013 \\
\hline & $\begin{array}{c}\text { Lingkungan Kerja } \\
\text { (X2) }\end{array}$ & ,441 & ,103 & 438 & 4,300 & ,000 \\
\hline
\end{tabular}

a. Dependent Variable: Kinerja Karyawan (Y)

Multiple regression models or multiple linear regression equations are generally denoted by:

$\mathrm{Y}=\mathrm{a}+\mathrm{b} 1 \mathrm{X} 1+\mathrm{b} 2 \mathrm{X} 2+\mathrm{ei}$

The regression equation can be seen from the coefficient table, so it can be written as follows:

$\mathrm{Y}=15,755+0,323 \mathrm{X} 1+0,441 \mathrm{X} 2+\mathrm{ei}$

Information:

$\mathrm{Y}=$ Employee Performance

$\mathrm{X} 1=$ Training

$\mathrm{X} 2=$ Work Environment 
Interpretation:

A constant of 15,755 , meaning that if the value of training (X1) and work environment (X2) is 0 , then the employee's performance (Y) is 15,755

The training variable regression coefficient $(\mathrm{X} 1)$ is 0.323 , meaning that if the training variable increases by one unit, the employee performance variable $(\mathrm{Y})$ will increase by 0.323 units.

The work environment variable regression coefficient (X2) is 0.441 , which means that the work environment variable has increased by one unit, then the employee performance variable $(\mathrm{Y})$ has increased by 0.441 units.

It is known that the second variable has a positive regression coefficient. This means that the provision of job training and work environment will improve the performance of employees at PT Marindo Makmur Usahajaya.

\subsection{Hypothesis test}

\subsubsection{T test}

Coefficients ${ }^{\mathrm{a}}$

Table 7. T test

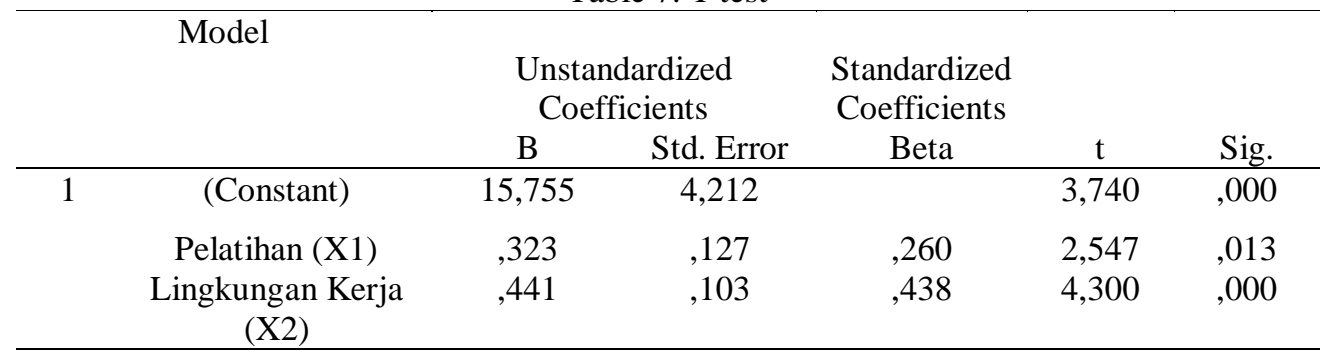

a. Dependent Variable: Kinerja Karyawan $(\mathrm{Y})$

Based on the table data above in the T test (partial) above, it is known that the significant value of the training variable $(\mathrm{X} 1)$ is $2.547>0.05$ so that the training variable (X1) has a significant effect on the employee performance variable (Y). The Work Environment variable (X2) is 4,300 $<0.05$ so that these results have an effect on the Employee Performance variable (Y). Thus the training and work environment variables have a significant influence on employee performance variables.

$\mathrm{H} 1$ : It is known that the sig value for the effect of $\mathrm{X} 1$ on $\mathrm{Y}$ is equal to $0.000<0.05$ and the $\mathrm{t}$ value of 2.547> $\mathrm{t}$ table 1.993 so that it can be concluded that $\mathrm{H} 1$ is accepted, which means that there is a significant effect of $\mathrm{X} 1$ on $\mathrm{Y}$.

H2: It is known that the sig value for the effect of $\mathrm{X} 2$ on $\mathrm{Y}$ is equal to $0.000<0.05$ and the $\mathrm{t}$ value of $4.300>$ $\mathrm{t}$ table 1.993 so that it can be concluded that $\mathrm{H} 1$ is accepted, which means that $\mathrm{X} 2$ has a significant effect on $\mathrm{Y}$.

\subsubsection{F test}

ANOVA $^{\mathrm{b}}$

Table 8. F test

\begin{tabular}{ccccccc}
\hline & Model & Sum of Squares & df & Mean Square & F & Sig. \\
\hline 1 & Regression & 707,203 & 2 & 353,601 & 23,678 &, $000^{\mathrm{a}}$ \\
& Residual & 1194,677 & 80 & 14,933 & & \\
Total & 1901,880 & 82 & & & \\
\hline
\end{tabular}

a. Predictors: (Constant), Lingkungan Kerja (X2), Pelatihan (X1)

b. Dependent Variable: Kinerja Karyawan (Y)

Based on the output above, it is known that the significance value of the effect of X1 and X2 simultaneously on $\mathrm{Y}$ is equal to $0.000<0.05$ and the value of Fcount 23.678> Ftable 3.11. So it can be concluded that $\mathrm{H} 3$ is accepted, which means that there is an effect of $\mathrm{X} 1$ and $\mathrm{X} 2$ simultaneously on $\mathrm{Y}$. 


\subsection{Coefficient of Determination (R2)}

Table 9. Coefficient of Determination (R2)

Model Summary

\begin{tabular}{|l|l|r|r|r|}
\hline Model & $\mathrm{R}$ & $\mathrm{R}$ Square & \multicolumn{1}{|c|}{$\begin{array}{c}\text { Adjusted } \mathrm{R} \\
\text { Square }\end{array}$} & $\begin{array}{c}\text { Std. Error of } \\
\text { the Estimate }\end{array}$ \\
\hline 1 &, $610^{\mathrm{a}}$ &, 372 &, 356 & 3,86438 \\
\hline
\end{tabular}

a. Predictors: (Constant), Lingkungan Kerja (X2), Pelatihan

(X1)

Based on the output above, it is known that the R Square value is 0.372 . This means that the effect of variables $\mathrm{X} 1$ and $\mathrm{X} 2$ simultaneously on variable $\mathrm{Y}$ is $37.2 \%$ and the remaining $62.8 \%$ is influenced by other variables not examined in this study.

\subsection{Discussion}

From the results of data analysis shows that partially job training variables have an effect on employee performance variables, the significance value is greater than $0.05(0.000<0.05)$ tcount $>$ ttable $(2.547>1.993)$. While work environment variables also affect employee performance variables based on a significance value greater than $0.05(0.000<0.05)$ tcount <ttable $(4.300>1.993)$.

From the results of data analysis shows that simultaneously job training and work environment variables affect employee performance variables with a significance value of 0.000 less than $0.05(0.000<0.05)$, while if seen from the Fcount value 23.678 is greater than Ftable value $(23,678>3,11)$. Thus, it can be ignored that job training and work environment variables have an effect on employee performance variables. The value of $R$ Square is 0.372 .

\section{Conclusions and Suggestions \\ 5.1. Conclusion}

Based on the analysis that has been done, some conclusions can be drawn as follows:

1. The results of the data show that partially the training variable (X1) affects the employee performance variable $(\mathrm{Y})$, the significance value is greater than $0.05(0.000<0.05)$ tcount> ttable $(2.547>1.993)$, it can be concluded that job training variables have an effect on employee performance.

2. The results of data analysis show that partially the work environment variable (X2) also affects the employee performance variable $(\mathrm{Y})$, based on a significance value greater than $0.05(0.000>0.05)$. And if it is seen from the value of tcount> ttable (4.300>1.993), it can be concluded that the work environment affects employee performance.

3. The results of data analysis show that simultaneously the Fcount of 23.678> Ftable is 3.11 and a sig value of 0.05 , it can be concluded that there is a significant influence between job training (X1), work environment (X2) and a significant effect on performance. employee (Y).

4. The test results of the coefficient of determination (R2) obtained a value of 0.372 or about $37.2 \%$. So it can be seen that the influence of training and work environment variables on employee performance is $37.2 \%$ and the remaining $62.8 \%$ is influenced by other factors or variables not examined in this study.

\subsection{Suggestion}

Based on the above conclusions, the authors provide several suggestions which are expected to be useful for PT. Marindo Makmur Usahajaya are as follows:

1. For companies

Based on the results of the research, it is hoped that companies both that are the subject of this research and outside of this study can pay attention to the following aspects:

- In the training variable, the company needs to improve the material provided with the difficulty level of the job. Companies can recruit specialists who focus on specific skills to provide training to employees. Such a move would allow more for employee performance.

- In general, the work environment variable is good, only the noise problem needs to be fixed. Like controlling noise so as not to disturb anymore. This can be done by attaching a damper to the device in question.

- In the employee performance variable, from several aspects the employees have worked well, but the company needs to prepare a strategy so that employees feel at home working overtime to meet this high morale. Such as free snacks, appreciation, work atmosphere without pressure. 
2. For employees

Must attend training conducted by the company. The results of the training are expected to provide more knowledge and insight to employees in working at the company so that their performance and quality are getting better.

3. For researchers

Subsequent research is to test other variables in improving employee performance such as variables of salary, compensation, productivity, and others.

\section{References}

Dessler, G. (2011) Human Resource Management. Global Edition Pearson. Available at: https://www.pearson.com/us/higher-education/product/Dessler-Human-Resource-Management-12thEdition/9780136089957.html.

Hasibuan, M. S. P. (2012) Manajemen Sumber Daya Manusia. Jakarta: PT. Bumi Aksara. Available at: https://onesearch.id/Record/IOS2726.slims-90951.

Mangkunegara, A. A. A. P. (2011) Manajemen Sumber Daya Manusia Perusahaan. Bandung: PT. Remaja Rosda Karya.

Sedarmayanti (2013) Manajemen Sumber Daya Manusia. Bandung: Refika Aditama.

Sugiyono (2013) Metode Penelitian Kuantitatif, Kualitatif dan $R \& D$. Depok: Rajawali Pers. Available at: https://onesearch.id/Record/IOS2726.slims-51273.

Suwatno and Priansa, D. J. (2011) Manajemen SDM dalam organisasi Publik dan Bisnis. Bandung: Alfabeta. 